\title{
Use of alcoholic extract of onion peel (Allium cepa L.) to control Fusarium moniliforme
}

\begin{abstract}
Background: The present work had as objective the control of the fungus Fusarium moniliforme in vitro, based on alcoholic extract of onion bark. In preparation of the extract, 150 grams of onion was used, with 1 liter of alcohol. Then placed in a film with a 96 hour film, after which time the extract was filtered with the aid of a sterile gauze, placed in a dark vial and carried a refrigerator where it was held for 72 hours so that the excess alcohol evaporated. The alcoholic extract of onion peel showed control in the mycelial development of the fungus, and we conclude that the onion bark has efficient metabolites for the control of the fungus Fusarium moniliforme, and presenting significant results.
\end{abstract}

Keywords: biological control, organic extract, natural Fungicide, fungicidal activity
Volume 7 Issue 4 - 2018

\author{
Danilo Miralha Franco, Leonardo Gomes \\ Longo, Angelo Ricardo Garcia \\ Department of Agronomic Engineering, Faculdades Gammon, \\ Brazil
}

Correspondence: Angelo Ricardo Garcia, Department of Agronomy, Faculdades Gammon, Rua Prefeito Jayme Monteiro, 791, Paraguaçu Paulista City, Zip code 19700000, Brazil, Tel +55 18 33619492,Email angelo_ric@hotmail.com

Received: August 04, 2017 | Published: August 29, 2018

\section{Introduction}

The maize (Zea mays L.) crop has a great economic and social role in Brazil occupying a cultivated area, in the 2015/16 crop, around 15279.3 million hectares, with a production of 82043.6 tons, presenting a productivity of $5370 \mathrm{~kg}$ ha- $1 .{ }^{1}$ The importance of maize cultivation mainly refers to its chemical composition, composed of nutrients such as vitamins, minerals, proteins and carbohydrates, mainly the starch evidenced by its employability in the food industry and renewable fuels, besides the generation of income due to the extensive cultivated area worldwide., ${ }^{2,3}$

The increase in maize yield depends on several factors, such as yield potential of the genotype and its resistance to diseases, soil fertility, adequate plant density, cropping system (rotation or monoculture), sowing system (conventional or direct), pest and disease management and environmental conditions. In relation to the diseases, corn stem base rot is related to the development capacity of the fungus Fusarium moniliforme, and can cause severe damage and is worthy of note due to its economic repercussions. The stem infection compromises the uptake of water and nutrients from the soil to the aerial organs of the plant affecting potential yield and grain quality. ${ }^{4,5}$ The main symptoms observed in the plant are discoloration of the bark, perithecia or picnidia signs on the surface and lower pressure resistance of the stem base in the first and second internodes above the soil surface are indicative of the presence of stem rot. ${ }^{6}$

Located in a tropical area, Brazil presents psychrometric conditions of the air that favor the development of fungi. These microorganisms are widely distributed in the environment, and agriculture in conditions for their multiplication, can contaminate from seed, equipment and storage facilities, causing losses in agricultural production. ${ }^{7}$

In addition, the use of chemical fungicide has shown little efficiency and high contamination index to the ecosystem. Therefore, the stimulation of new control methods and the use of natural fungicides that do not harm the environment are important for the new challenges of modern agriculture. ${ }^{8,9}$ In this context, the onion (Allium cepa) presents great production and the bark of its bulbs are generally considered residues of the production, but this genus has in the literature reports of its fungicide action because they present secondary metabolites, mainly flavonols and because they are rich in sulfur. ${ }^{10}$ Therefore, they can be used for maize crop management and avoid the proliferation of microorganisms that cause stem base rot.

\section{Material and methods}

\section{Bioassay}

The experimental design was completely randomized, consisting of 3 treatments and 10 replicates, totaling 30 Petri dishes.

a. Control-containing only $20 \mathrm{ml}$ of PDA (potato-dextrose-agar).

b. Negative control-20ml of PDA $+10 \%(0.2 \mathrm{ml})$ of absolute alcohol.

c. Treatment- $20 \mathrm{ml}$ of PDA $+10 \%(0.2 \mathrm{ml})$ of alcoholic extract of onion peel.

\section{Cultivation of the phytopathogen Fusarium moniliforme}

Fusarium moniliforme fungus was isolated from corn seeds (Zea mays). This fungus was isolated in 10petri dishes, PDA and subsequently kept at $25^{\circ} \mathrm{C}$ for 7 days.

\section{Obtaining the alcoholic extract of onion peel}

For the preparation of the alcoholic extract, onion peels were collected and weighed $150 \mathrm{~g}$. They were then crushed with one liter of absolute alcohol. This crude extract was rested on Becker capped with film paper for 96 hours. Subsequently, this extract was filtered on sterile gauze, then placed in a dark vial and taken to the refrigerator where it was held for 72 hours. The vial remained with a gauze on its surface so that excess alcohol evaporated.

\section{Results and discussion}

The results presented in Figure 1 demonstrated that the alcoholic extract of onion peel had a positive effect and was efficient in controlling the development of $F$. moniliforme. Treatment with onion peel extract inhibited $100 \%$ mycelial fungal development compared to control.

Contrary to Pereira et al., ${ }^{11}$ using essential oil of onion peel, and did not observe inhibition of the mycelial development of Aspergillus 
flavus and Fusarium sp. concentrations tested by them. Silva et al., ${ }^{12}$ working with aqueous garlic extract and clove extract showed significant antifungal activity on the mycelial growth of Fusarium oxysporum. This difference may be related to the extraction technique, since the essential oil is rich in metabolites of the terpenes class (mono- and sesquiterpenes) of low molecular weight, while alcoholic and aqueous extraction favors the concentration of polar compounds of higher molecular weight, such as those of the class of flavonols which the fungicidal activity of this species is related. ${ }^{10}$

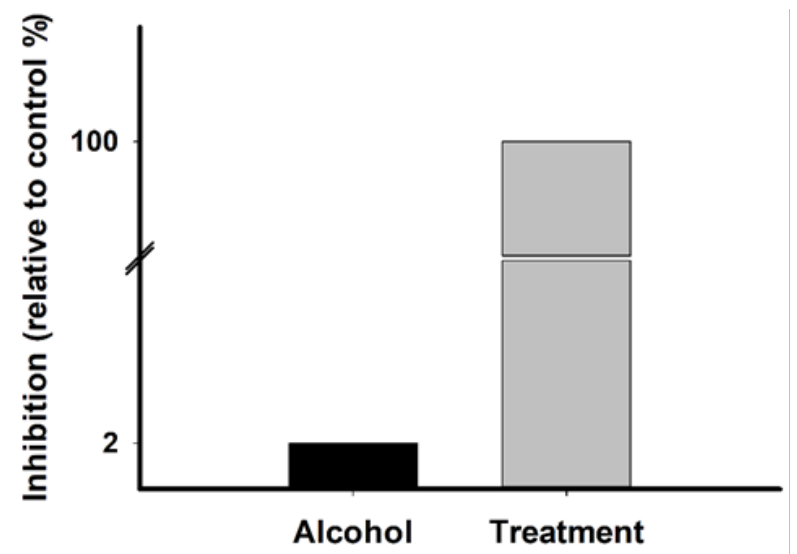

Figure I Mean results of in vitro inhibition of Fusarium moniliforme in the alcoholic control and treatment with alcoholic extract of onion peel at $10 \%$.

\section{Conclusion}

In conclusion, the alcoholic extract of onion peel also presents compounds with antifungal activity in its composition and presents efficiency in the inhibition of the mycelial growth of Fusarium moniliforme in vitro. Thus, its application can be indicated in vivo as a natural alternative to chemical fungicides.

\section{Acknowledgements}

None.

\section{Conflict of interest}

Authors declare that there is no conflict of interest

\section{References}

1. CONAB. Acompanhamento da Safra Brasileira: Grãos 2016/2017. 2016.

2. Strazzi S. Derivados do milho são usados em mais de 150 diferentes produtos industriais. Rev Visão Agrícola-USP/ESALQ. 2015: 146-150.

3. Gasperini AM. Biocontrole de Fusarium verticillioides em milho. 2011.

4. Christensen JJ, Wilcoxson RD. Stalk rot of corn. The American Phytopathological Society. 1966.

5. Denti,EA, Reis EM. Levantamento de fungos associados às podridões do colmo e quantificação de danos em lavouras de milho do planalto médio gaúcho e dos campos gerais do Paraná. Fitopatol Bras. 2003;28:585-590.

6. Bacon CW, Yates IE, Hinton DM, et al. Biological control of Fusarium moniliforme in maize. Environ Health Perspect. 2001;109:325-332.

7. Cleveland TE, Dowd PF, Desjardins AE, et al. United States Department of Agriculture-Agricultural Research Service research on pre-harvest prevention of mycotoxins and mycotoxigenic fungi in US crops. Pest Manag Sci Former Pestic Sci. 2003;9:629-642.

8. Batista SMB. Estudo da atividade antifúngica do Netrix sobre cinco espécies fúngicas e superfície interna de um silo. 2010.

9. Lima RA, Neto MF. Atividade Antifúngica do Extrato Etanólico dos Frutos de Solanum grandiflorum sobre Rhizoctonia solani in vitro. Saúde e Pesqui. 2013;7.

10. Ren F, Reilly K, Kerry JP, et al. Higher Antioxidant Activity, Total Flavonols, and Specific Quercetin Glucosides in Two Different Onion (Allium cepa L.) Varieties Grown under Organic Production: Results from a 6-Year Field Study. J Agric Food Chem. 2017;65:5122-5132.

11. Pereira MC. Inibição do desenvolvimento fúngico através da utilização de óleos essenciais de condimentos. Ciência e Agrotecnologia. 30. 2006:731738 .

12. da Silva JL, Teixeira RNV, Santos DIP, et al. Atividade antifúngica de extratos vegetais sobre o crescimento in vitro de fitopatógenos. Rev Verde Agroecol e Desenvolv Sustentável. 2012;7:80-86. 